\title{
C-reactive protein inhibits adiponectin gene expression and secretion in 3T3-L1 adipocytes
}

\author{
Guoyue Yuan ${ }^{1,2, *}$, Xia Chen ${ }^{1, *}$, Qinyun $\mathrm{Ma}^{1, *}$, Jie Qiao ${ }^{1}$, Rongying $\mathrm{Li}^{1}$, Xuesong $\mathrm{Li}^{1}$, Shengxian $\mathrm{Li}^{3}$, \\ Jinfeng Tang ${ }^{1}$, Libin Zhou ${ }^{1}$, Huaidong Song ${ }^{1}$ and Mingdao Chen ${ }^{1}$ \\ ${ }^{1}$ State Key Laboratory of Medical Genomics, Shanghai Institute of Endocrine and Metabolic Diseases, Center of Molecular Medicine, Ruijin Hospital, Shanghai \\ Jiaotong University Medical School, 197, Ruijin Road II, Shanghai 200025, China \\ ${ }^{2}$ Department of Endocrinology, The Affiliated Hospital of Jiangsu University, Zhenjiang, Jiangsu 212001, China \\ ${ }^{3}$ Department of Endocrinology, Renji Hospital, 1630, Dongfang Road, Pudong, Shanghai 210127, China \\ (Request for offprints should be addressed to H Song; Email: huaidong_s1966@163.com; M Chen; Email: mingdaochensh@yahoo.com) \\ *(G Yuan, X Chen and Q Ma contributed equally to this work)
}

\begin{abstract}
C-reactive protein (CRP) is considered as one of the most sensitive markers of inflammation. The aim of the present study is to investigate the effects of CRP on the production of adiponectin in 3T3-L1 adipocytes. Northern and western blot analysis revealed that CRP treatment inhibited adiponectin mRNA expression and secretion in a dose- and time-dependent manner. Co-incubation of adipocytes with rosiglitazone and CRP decreased induction of adiponectin gene expression by rosiglitazone. However, luciferase reporter assays did not show that CRP affected the activity of $\sim 2 \cdot 1 \mathrm{~kb}$
\end{abstract}

adiponectin gene promoter, which was increased by rosiglitazone alone. Pharmacological inhibition of phosphatidylinositol (PI)-3 kinase by LY294002 partially reversed inhibition of adiponectin gene expression by CRP. These results collectively suggest that $\mathrm{CRP}$ suppresses adiponectin gene expression partially through the PI-3 kinase pathway, and that decreased production of adiponectin might represent a mechanism by which CRP regulates insulin sensitivity.

Journal of Endocrinology (2007) 194, 275-281

\section{Introduction}

Adipose tissue is now recognized to be an important endocrine organ, secreting a variety of polypeptides (adipokines) that are involved in the regulation of energy metabolism, immune response, and cardiovascular tone (Chaldakov et al. 2003, Lyon et al. 2003). Adiponectin is an important adipokine exclusively secreted from adipose tissue (Berg et al. 2002). Growing evidence suggests that adiponectin is an insulin-sensitizing hormone with direct antidiabetic, anti-atherogenic, and anti-inflammatory potentials (Berg et al. 2002, Chaldakov et al. 2003). Consistent with an insulin-sensitizing effect, transgenic ablation of adiponectin in mice induces insulin resistance (Kubota et al. 2002, Maeda et al. 2002), whereas transgenic overexpression (Yamauchi et al. 2002, Combs et al. 2004) improves insulin sensitivity. Interestingly, adiponectin also protects mice from atherosclerosis (Kubota et al. 2002, Yamauchi et al. 2003). Plasma levels of adiponectin correlate closely with systemic insulin sensitivity, and decreased adiponectin concentrations (hypoadiponectinemia) were observed in patients with type 2 diabetes, insulin resistance, or coronary heart disease (Hotta et al. 2000, Weyer et al. 2001). Several prospective studies suggest that a decline in plasma adiponectin concentration preceded the decrease in insulin sensitivity, suggesting that adiponectin deficiency might be an important causative factor of insulin resistance (Hotta et al. 2001, Lindsay et al. 2002). Indeed, several insulin resistance inducing factors, such as tumor necrosis factor $\alpha$, interleukin 6 , dexamethasone and isoproterenol, have been shown to reduce adiponectin production (Fasshauer et al. 2001, 2002, 2003). On the other hand, the peroxisome proliferator-activated receptor $(\mathrm{PPAR}) \gamma$ agonists thiazolidinediones (TZD), which are used clinically as insulin sensitizing drugs, increased adiponectin expression and its plasma concentrations in rodents and human subjects (Maeda et al. 2001, Combs et al. 2002).

C-reactive protein (CRP) is one of the most sensitive inflammatory markers. An association of CRP to the development of atheroscleroticdisease has been observed in experimental and epidemiological studies (Ridker et al. 2000, Libby et al. 2002). Recent studies have shown that elevation of CRP concentrations is an independent predictive parameter of type 2 diabetes mellitus (DM; Festa et al. 2002, Freeman et al. 2002), which is also strongly associated with various components of the metabolic syndrome (Frohlich et al. 2000, Aronson et al. 2004). A number of studies reported that serum highly sensitive CRP (hs-CRP) is negatively correlated with insulin sensitivity index (SI) and 
serum adiponectin in some subjects (Ouchi et al. 2003, Schulze et al. 2004, Yuan et al. 2006). However, it has not been determined so far whether increased CRP level is a cause or an effect of insulin resistance and decreased adiponectin.

In the current study, we therefore examined the effect of CRP on adiponectin gene expression and secretion in 3T3-L1 adipocytes in vitro. We demonstrated that CRP suppressed adiponectin mRNA expression and secretion in a dose- and time-dependent manner. Furthermore, we found that pharmacological inhibition of phosphatidylinositol (PI)-3 kinase by LY294002 partially reversed inhibition of adiponectin gene expression by CRP. These results collectively suggest that CRP suppresses adiponectin gene expression partially through the PI-3 kinase pathway.

\section{Materials and Methods}

\section{Materials}

Insulin, dexamethasone, methyl-isobutyl-xanthine, antiadiponectin antibody, AG490, PD98059, SB203580, and LY294002 were purchased from Sigma. Human recombinant CRP was obtained from Calbiochem (La Jolla, CA, USA). Rosiglitazone was generously provided by Shanghai Sunve Pharmaceutical Co., Ltd. Goat anti-rabbit IgG-HRPconjugated secondary antibody was obtained from Dako (Glostrup, Denmark). Enhanced chemiluminescence (ECL) reagents were purchased from Pierce (USA). Trizol Reagent and lipofectamine 2000 were purchased form Invitrogen. DIG Northern Starter Kit was purchased from Roche. Dual luciferase reporter system and the reporter vectors pGL3basic and pRL-SV40 are the products of Promega Corporation.

\section{Cell culture and differentiation}

3T3-L1 cells were maintained as subconfluent cultures in Dubecco's modified Eagle's medium (DMEM) supplemented with 10\% fetal bovine serum and differentiated with DMEM supplemented with $5 \mathrm{mg} / \mathrm{ml}$ insulin, $0.5 \mathrm{mmol} / 1$ 1-methyl3 -isobutyl-xanthin, and $1 \mathrm{mmol} / 1$ dexamethazone 2 days after reaching confluence.

\section{Analysis of adiponectin gene expression by northern blot}

Total RNA was extracted from 3T3-L1 adipocytes using Trizol Reagents according to the manufacturer's instructions. Northern blot analysis was performed using non-isotopic DIG Northern Starter Kit as we previously described (Li et al. 2004). Target fragment (murine adiponectin) was cloned into PGEM-T easy vector and confirmed by automated sequencing. DIG-labeled probe was generated by transcription with sp6 RNA polymerase using the DIG Northern starter kit. Ten micrograms of total RNA per lane were used for northern blot analysis.

\section{Quantification of adiponectin concentration by western blot}

Media adiponectin concentration was measured by western blot. Media of $7 \cdot 5 \mu \mathrm{l}$ were subjected to western blot to detect the amount of adiponectin that was secreted during CRP exposure. Proteins were separated by $12 \cdot 5 \%$ SDS-PAGE gel, followed by electrophoretic transfer to a nitrocellulose membrane. Membranes were incubated overnight at $4{ }^{\circ} \mathrm{C}$ with anti-adiponectin antibody (1:2000), and incubated for at least $1 \mathrm{~h}$ at room temperature with goat anti-rabbit IgGHRP-conjugated secondary antibody (1:2000). The signal was detected using the ECL system. The amount of adiponectin was normalized to cell number.

Cloning of human adiponectin promoter and construction of the luciferase reporter vector

A $\sim 2.1 \mathrm{~kb}$ promoter segment corresponding to the range -2114 to $+4 \mathrm{bp}$ of the human adiponectin gene was amplified using the forward primer

CTGTAGGTACCGGGCATGAGGAATTAGAAAGCA and the reverse primer TAGAACTCGAGAATGGAAGTGAGGAGGAGATGG respectively. The DNA fragment was digested with kpn1 and XhoI, and subcloned into PGL3basic vector. The sequence of the cloned DNA fragment was confirmed by DNA sequencing.

\section{Transient transfection and luciferase reporter assays}

3T3-L1 adipocytes at day 7 after differentiation were transfected with the luciferase reporter vectors using Lipofectamine 2000 (Maeda et al. 2001, Xu et al. 2004). Luciferase assays were conducted using the Dual-Luciferase Reporter System (Promega). Transiently transfected cells were solubilized in $150 \mu \mathrm{l}$ lysis buffer. After centrifugation to remove cell debris, $20 \mu \mathrm{l}$ cell lysate was used to measure luciferase activity according to the manufacturer's instructions. In each measurement, luciferase units were normalized for background and transfection efficiency as determined by the 'Renilla' luciferase activity of the co-transfected pRL-SV40 plasmid.

\section{Statistical analysis}

Results were reproduced in at least three independent experiments. The results are presented as means of at least triplicate determinations \pm s.D. Significance was determined by Student's $t$-test or one-way ANOVA. In all statistical comparisons, a $P$ value of $<0.05$ was considered statistically significant. 


\section{Results}

CRP inhibits adiponectin $m R N A$ expression in a dose- and time-dependent manner

To evaluate the effect of CRP on adiponectin gene expression, we treated 3T3-L1 adipocytes with different concentrations of CRP for $24 \mathrm{~h}$. Northern blot analysis revealed that CRP treatment inhibited adiponectin mRNA expression in a dose-dependent manner with significant 31\% inhibition detectable with CRP concentrations at $25 \mu \mathrm{g} / \mathrm{ml}$ $(P<0 \cdot 01)$ and a maximal $52 \%$ decrease found at $50 \mu \mathrm{g} / \mathrm{ml}$ $(P<0 \cdot 01$; Fig. 1A).

Furthermore, adiponectin mRNA expression was suppressed in a time-dependent manner with significant $42 \%$ inhibition detectable at $12 \mathrm{~h}$ of CRP treatment and a maximal 52\% inhibition observed at $24 \mathrm{~h}$ after CRP addition $(P<0 \cdot 01$; Fig. 1B).

Adiponectin secretion is inhibited by CRP in a dose- and timedependent manner

Next, we determined whether changes in adiponectin mRNA expression would be paralleled by protein secretion. In fact, adiponectin secretion was suppressed in a dosedependent manner with $19 \%$ inhibition detectable with CRP concentration at $25 \mu \mathrm{g} / \mathrm{ml}(P<0 \cdot 05)$ and a $41 \%$ significant reduction found at $50 \mu \mathrm{g} / \mathrm{ml}(P<0 \cdot 01$; Fig. 2A). CRPtreatment inhibited adiponectin secretion also in a timedependent manner with significant $29 \%$ inhibition detectable at $12 \mathrm{~h}$ of CRP treatment and a maximal $41 \%$ reduction found at $24 \mathrm{~h}(P<0 \cdot 01$; Fig. $2 \mathrm{~B})$.
Inhibition of adiponectin $m R N A$ expression by CRP is partially mediated via PI-3 kinase pathway

Recently, the major steps in CRP signaling have been elucidated. Signaling proteins such as PI-3 kinase have been implicated in CRP signaling. We further tested whether signaling proteins such as Janus kinase 2 (Jak2), P42/44 mitogen-activated protein (MAP) kinase, P38 MAP kinase, and PI-3 kinase might play a role in the downregulation of adiponectin gene expression. For this purpose, 3T3-L1 adipocytes were pretreated with specific pharmacological inhibitors for $1 \mathrm{~h}$ before CRP $(50 \mu \mathrm{g} / \mathrm{ml})$ was added for $24 \mathrm{~h}$. Each individual pharmacological inhibitor alone tended to decrease adiponectin mRNA expression (Fig. 3A). Again, adiponectin mRNA was decreased by $52 \%$ after 24 h of CRP treatment $(P<0 \cdot 01$; Fig. 3B). Interestingly, inhibition of PI-3 kinase by LY294002 $(10 \mu \mathrm{M})$ significantly reversed this inhibition and adiponectin expression recovered $77 \%$ of wild-type levels (Fig. 3B). In contrast, inhibition of Jak2, p44/ 42 MAP kinase, and p38 MAP kinase with AG490 (25 $\mu \mathrm{M})$, PD $98059(25 \mu \mathrm{M})$, and SB203580 $(25 \mu \mathrm{M})$ respectively did not significantly influence the inhibition of adiponectin gene expression by CRP (Fig. 3B).

CRP and PPAR $\gamma$ agonist affect adiponectin gene expression via distinct pathways

The expression of adipoectin has been shown to be under the control of the transcription factor PPAR $\gamma$. The PPAR $\gamma$ agonists TZD was shown to be able to increase plasma adiponectin levels in humans and mice. Consistent with previous reports, we found that the PPAR agonist
A
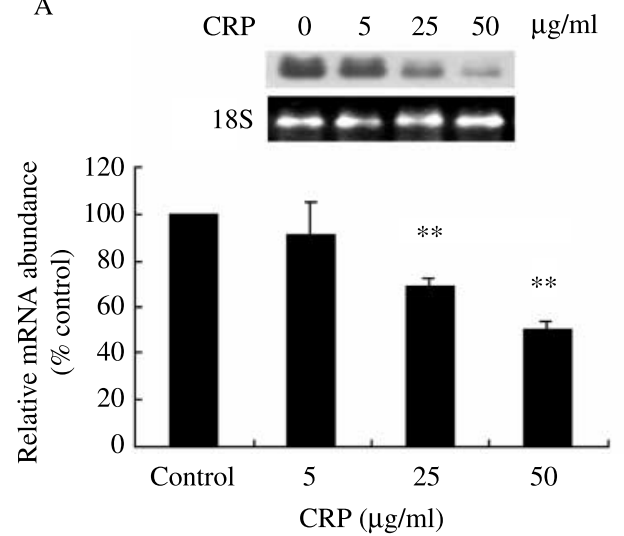

B $\begin{array}{lllllll}\text { CRP } & 0 & 2 & 4 & 8 & 12 & 24\end{array}$
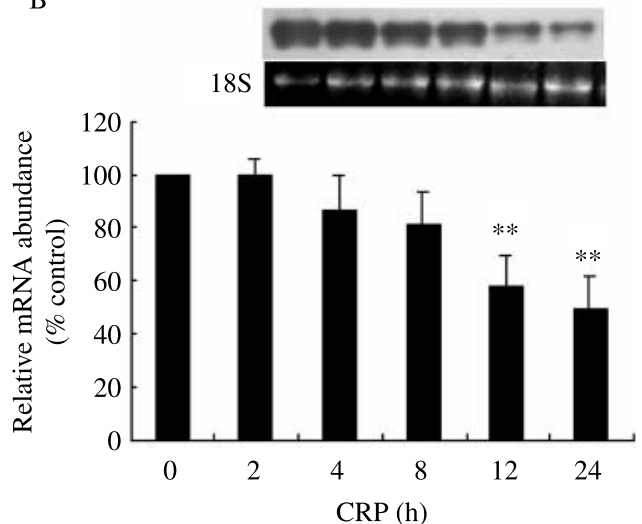

Figure $1 \mathrm{CRP}$ inhibits adiponectin mRNA expression in a dose- and time-dependent manner (A) Dosedependent inhibition of adiponectin mRNA expression by CRP $(24 \mathrm{~h})$. (B) Time-dependent inhibition of adiponectin mRNA expression by CRP $(50 \mu \mathrm{g} / \mathrm{ml})$. Differentiated 3-L1 cells were serum-deprived overnight before CRP was added. Total RNA was extracted and subjected to northern blot as described in Materials and Methods. Adiponectin mRNA levels normalized to $18 \mathrm{~S}$ rRNA expression were determined relative to untreated control cells $(100 \%)$. Data represent means \pm S.E.M. of three independent experiments. ${ }^{* *}$ Denotes $P<0.01$ comparing CRP-treated with non-treated adipocytes. 
A

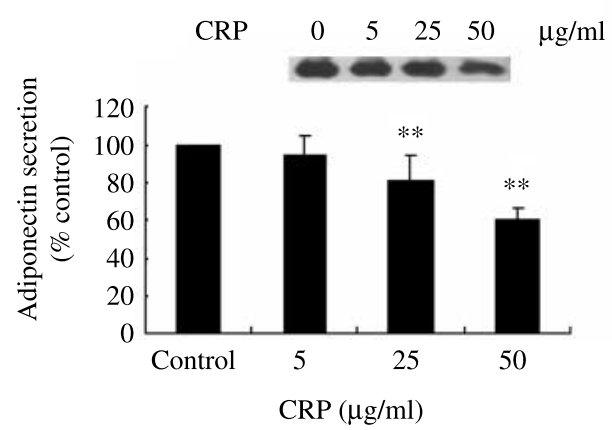

B

Figure 2 Adiponectin secretion is inhibited by CRP in a dose- and time-dependent manner. (A) Dosedependent inhibition of adiponectin secretion by CRP $(24 \mathrm{~h})$. (B) Time-dependent inhibition of adiponectin secretion by CRP $(50 \mu \mathrm{g} / \mathrm{ml})$. Differentiated 3T3-L1 cells were serum-deprived overnight before CRP was added. $7 \cdot 5 \mu \mathrm{l}$ of the media was subjected to western blot to detect the amount of adiponectin that was secreted. The amount of adiponectin was normalized to cell number. Data are expressed relative to untreated control (Con) cells (100\%) and represent means \pm S.E.M. of three independent experiments. *Denotes $P<0 \cdot 05,{ }^{* *} P<0 \cdot 01$ comparing CRP-treated with untreated control cells.

rosiglitazone enhanced adiponectin mRNA expression by 1.7-fold (Fig. 4A), while $25 \mu \mathrm{g} / \mathrm{ml}$ CRP decreased adiponectin gene expression by $31 \%$. Co-incubation of cells with CRP and rosiglitazone decreased induction of adiponectin gene expression by rosiglitazone (Fig. 4A).

Finally, we further investigated the effects of CRP on the activity of $\sim 2 \cdot 1 \mathrm{~kb}$ human adiponectin gene promoter, which includes the $\operatorname{PPAR} \gamma$ responsive elements. The addition of $10 \mu \mathrm{M}$ rosiglitazone significantly increased PPAR $\gamma$ activity (by 15 -fold), whereas CRP $(25 \mu \mathrm{g} / \mathrm{ml})$ did not suppress the activity of $\sim 2 \cdot 1 \mathrm{~kb}$ human adiponectin gene promoter that was increased by rosiglitazone (Fig. 4B), suggesting that CRP and PPAR $\gamma$ agonist affect adiponectin gene expression via distinct pathways.

\section{Discussion}

CRP is one of the most sensitive inflammatory markers. An association of CRP to the development of

A

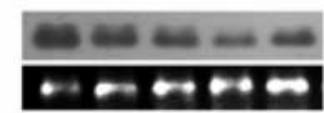

Adiponectin

$18 \mathrm{~S}$

Control AG PD SB LY

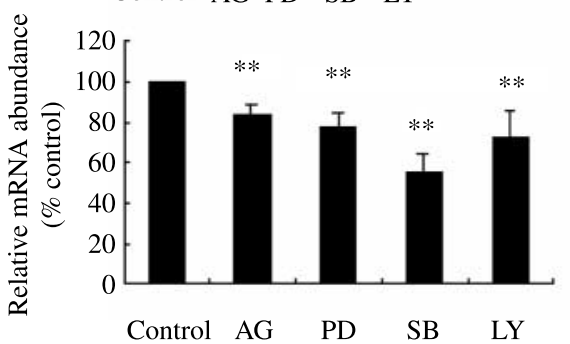

B

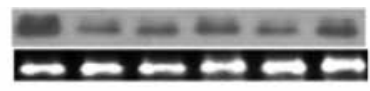

Adiponectin

Control CRP AG PD SB LY

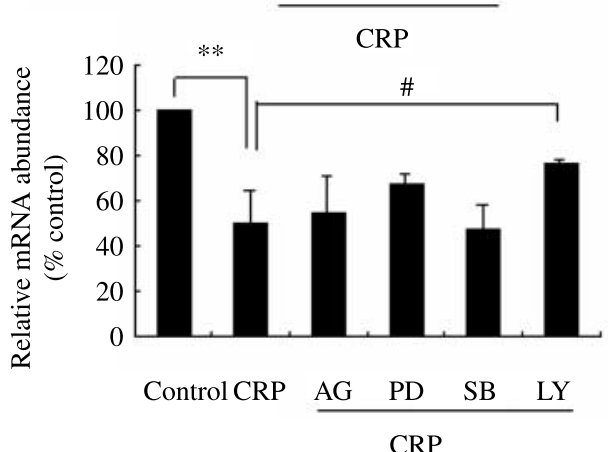

Figure 3 Inhibition of adiponectin mRNA by CRP is partially mediated via PI-3 kinase. (A) After overnight serum-starvation, differentiated 3T3-L1 adipocytes were cultured in the presence or absence of the Janus kinase 2 (JAK2) inhibitor AG490 (AG, $25 \mu \mathrm{M}$ ), the P42/44 mitogen-activated protein (MAP) kinase inhibitor PD98059 (PD, $25 \mu \mathrm{M}$ ), the P38 MAP kinase inhibitor SB203580 (SB, $25 \mu \mathrm{M}$ ), or the phosphatidylinositol-3 (PI-3) kinase inhibitor LY294002 (LY, $10 \mu \mathrm{M}$ ) for $25 \mathrm{~h}$. (B) After overnight serum-starvation, differentiated 3T3$\mathrm{L} 1$ adipocytes were cultured in the presence or absence of $25 \mu \mathrm{M} \mathrm{AG}, 2.5 \mu \mathrm{M} \mathrm{PD}, 25 \mu \mathrm{M} \mathrm{SB}$, or $10 \mu \mathrm{M} \mathrm{LY}$ for $1 \mathrm{~h}$ before CRP $(50 \mu \mathrm{g} / \mathrm{ml})$ was added for $24 \mathrm{~h}$. After extraction of total RNA, northern blot was performed as described in Materials and Methods and adiponectin gene expression normalized to 18S rRNA levels is expressed relative to untreated control cells $(100 \%)$. Results are means \pm s.E.M. of three independent experiments. **Denotes $P<0.01$ comparing specific pharmacological inhibitors or CRP treated with untreated, and "denotes $P<0 \cdot 05$ comparing LY294002 pretreated with CRP-treated cells respectively. 


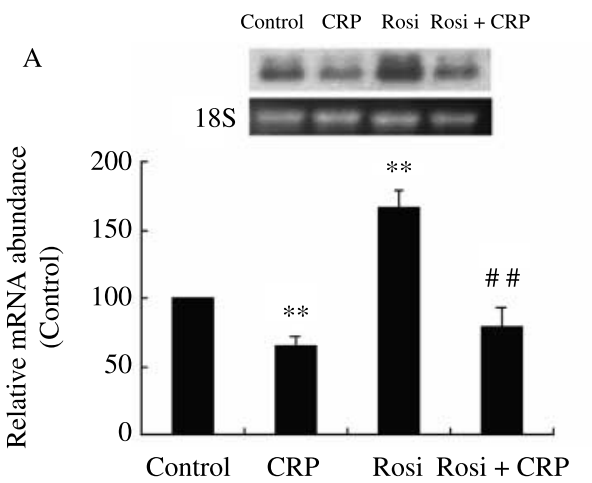

Figure 4 CRP and PPAR $\gamma$ affect adiponectin gene expression via distinct pathways. (A) Differentiated 3T3-L1 cells were serum-deprived overnight before CRP $(25 \mu \mathrm{g} / \mathrm{ml})$ and rosiglitazone $(10 \mu \mathrm{M})$ were added for $24 \mathrm{~h}$. Extraction of total RNA and northern blot determining adiponectin mRNA levels normalized to $18 \mathrm{~S}$ rRNA expression were done as described in Materials and Methods. Data are expressed relative to untreated control cells $(100 \%)$ and represent means \pm S.E.M. of three independent experiments. ${ }^{* *}$ Denotes $P<0 \cdot 01$ comparing with untreated control cells, and ${ }^{\# \#}$ denotes $P<0 \cdot 01$ comparing Rosi-treated with Rosi + CRPtreated cells respectively. (B) Adiponectin-luciferase and pRL-SV40 vector were co-transfected into day 7differentiated 3T3-L1 cells. For each 12-well dish, 1.5 $\mu$ g adiponectin-luciferase and $15 \mathrm{ng}$ pRL-SV40 were used. Six hours after transfection, rosiglitazone $(10 \mu \mathrm{M})$ or CRP $(25 \mu \mathrm{g} / \mathrm{ml})$ was supplemented to medium. At $24 \mathrm{~h}$ after transfection, cells were harvested, and firefly and Renilla luciferase reporter activity was measured as described in research and methods. Adiponectin-luciferase (firefly) activity was normalized by pRL-SV40 Renilla luciferase activity. Values are means \pm S.E.M. from three independent experiments. ${ }^{*}$ Denotes $P<0 \cdot 01$ compared with control values.

atheroscleroticdisease has been observed in experimental and epidemiological studies (Ridker et al. 2000, Libby et al. 2002). Recent studies have shown that elevation of CRP concentrations is an independent predictive parameter of type $2 \mathrm{DM}$ (Festa et al. 2002, Freeman et al. 2002), which is also strongly associated with various components of the metabolic syndrome (Frohlich et al. 2000, Aronson et al. 2004). Our group and others have reported that serum hs-CRP is inversely related to SI and serum adiponectin in certain defined subjects (Ouchi et al. 2003, Schulze et al. 2004, Yuan et al. 2006). However, to our knowledge, whether increased CRP level is a cause or an effect of insulin resistance or decreased adiponectin still remained unclear.

In the present study, we demonstrate for the first time that CRP suppresses adiponectin mRNA expression and secretion in a time- and dose-dependent manner. Adiponectin is a 244 amino acid adipose-specificprotein that has been shown to possess anti-atherogenic and anti-inflammatory properties (Ouchi et al. 1999, Yokota et al. 2000) in addition to improving glucose tolerance and insulin resistance in mouse diabetic models (Yamauchi et al. 2001). Similarly, adiponectin is related to insulin resistance and adiposity in humans (Weyer et al. 2001). Furthermore, recent study suggests that adiponectin is a protective factor against later development of diabetes (Lindsay et al. 2002). Our findings indicate that increased CRP level may lead to decreased adiponectin, and that decreased production of adiponectin seems to be a mechanism by which CRP regulates insulin sensitivity.

Recently, the major steps in CRP signaling have been elucidated (Marnell et al. 2005). CRP binds to Fc $\gamma$ R. Fc $\gamma$ R containing immunoreceptor tyrosine-based activation motifs

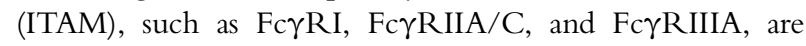
activated by clustering on the cell surface caused by ligand binding. This is followed by phosphorylation of the two tyrosines in the ITAM motif by Src-related tyrosine kinases such as Lyn, Fgr, and Hck. This leads to recruitment of Src homology 2-containing molecules such as Syk tyrosine kinase, which leads to a cascade of events: (1) phosphorylation of PI-3 kinase with the generation of $\mathrm{PI}(3,4,5) \mathrm{P}_{3}$, which promotes downstream signaling events, including phosphorylation of phospholipase $\mathrm{C} \gamma 2$ (PL C $\gamma 2$ ), which produces (a) diacylglycerol (DAG), which activates phosphokinase $\mathrm{C}$, which activates p38 transcription factor, and (b) calcium mobilization through inositol triphosphate $\left(\mathrm{IP}_{3}\right)$; (2) activation of Raf which binds Ras, phosphorylates MEK, which in turn phosphorylates ERK. Since pharmacological inhibition of PI-3 kinase by LY294002 partly reverses inhibition of adiponectin gene expression by CRP in the present study, PI-3 kinase is probably involved in adiponectin mRNA regulation by CRP. The PI-3 kinase is a ubiquitous, heterodimeric enzyme that plays a pivotal role in the regulation of many cellular processes, including motility, proliferation and survival, and carbohydrate metabolism. Bogan \& Lodish (1999) reported that insulin stimulates adiponectin release within $1 \mathrm{~h}$ and inhibitors of PI-3 kinase block insulin-stimulated adiponectin secretion. It indicates that short-term insulin-induced release of stored adiponectin is also mediated by a PI-3 kinase-dependent pathway. In line with our finding, previous studies have found that inhibition of either PI-3 kinase or p70S6 kinase using their specific pharmacological inhibitors partially reversed insulin-mediated suppression of 
adiponectin gene expression (Fasshauer et al. 2002, Xu et al. 2004), suggesting that PI-3 kinase/p70S6 kinase pathway is a suppressor of adiponectin gene expression.

The FOXO family of forkhead transcription factors is regulated by the $\mathrm{PI}-3$ kinase-protein kinase $\mathrm{B}$ (PKB)/Akt pathway (Burgering \& Kops 2002). A recent study (Davis et al. 2004) has shown that FoxC2 is associated with downregulationof adiponectin in 3T3-L1 preadipocytes. Therefore, in addition to PI-3 kinase/p70S6 kinase, CRP inhibits adiponectin gene expression which may be also through PI-3 kinase-PKB/Akt-FOXO pathway.

The transcriptional events that underlie the adiponectin gene expression remain poorly understood. The transcription factor PPAR $\gamma$, a key regulator of adipogenesis, has been shown to transactivate adiponectin gene expression (Maeda et al. 2001). The PPAR $\gamma$ agonist rosiglitazone increased adiponectin production in both animals and patients with diabetes (Combs et al. 2002). A more recent study has mapped the PPAR $\gamma$ responsive elements to a DNA fragment between -285 and -273 of the human adiponectin gene. In line with recent studies (Maeda et al. 2001, Xu et al. 2004), rosiglitazone could increase adiponectin gene expression. The activity of a $\sim 2.1 \mathrm{~kb}$ adiponectin gene promoter was increased by rosiglitazone. Co-incubation of adipocytes with rosiglitazone and CRP decreased induction of adiponectin gene expression while not affecting the activity of the adiponectin gene promoter induced by rosiglitazone. Our present study suggests that CRP and PPAR agonist affect adiponectin gene expression via distinct pathways.

Since adiponectin is an insulin-sensitizing hormone with direct anti-diabetic, anti-atherogenic, and anti-inflammatory potentials (Berg et al. 2002, Chaldakov et al. 2003), adiponectin deficiency appears to be an important causative factor of insulin resistance (Hotta et al. 2001, Lindsay et al. 2002). Hence, adiponectin replacement therapy may represent a novel strategy for the treatment of a variety of diseases, including insulin resistance, type 2 diabetes, and atherosclerosis (Berg et al. 2001, Fruebis et al. 2001, Yamauchi et al. 2001). Inhibition of CRP synthesis may be a strategy to increase endogenous adiponectin production.

In summary, our data clearly demonstrate that treatment of 3T3-L1 adipocytes with CRP significantly suppresses the expression and secretion of adiponectin in a dose- and timedependent manner, which seems partially mediated via PI-3 kinase pathway.

\section{Acknowledgements}

This work was jointly supported in part by grants from the Foundation for the Author of National Excellent Doctoral Dissertation of People's Republic of China (200154), the National Natural Science Foundation of China (30470816, 30530370, 30670987), the Education Commission of Shanghai (05BZ28), and the Science and Technology Commission of Zhenjiang City, Jiangsu Province (SG
2001094). All the funding mentioned in this article was supported by the government of China. There is no conflict of interest that would prejudice the impartiality of the research or a potential conflict of interest that is not fully declared within the text of the article.

\section{References}

Aronson D, Bartha P, Zinder O, Kerner A, Shitman E, Markiewicz W, Brook GJ \& Levy Y 2004 Association between fasting glucose and C-reactive protein in middle-aged subjects. Diabetic Medicine 21 39-44.

Berg AH, Combs TP, Du X, Brownlee M \& Scherer PE 2001 The adipocytesecreted protein Acrp30 enhances hepatic insulin action. Nature Medicine 7 947-953.

Berg AH, Combs TP \& Scherer PE 2002 ACRP30/adiponectin: an adipokine regulating glucose and lipid metabolism. Trends in Endocrinology and Metabolism 13 84-89.

Bogan JS \& Lodish HF 1999 Two compartments for insulin-stimulated exocytosis in 3T3-L1 adipocytes defined by endogenous ACRP-30 and GLUT4. Journal of Cell Biology 146 609-620.

Burgering BM \& Kops GJ 2002 Cell cycle and death control: long live Forkheads. Trends in Biochemical Sciences 27 352-360.

Chaldakov GN, Stankulov IS, Hristova M \& Ghenev PI 2003 Adipobiology of disease: adipokines and adipokine-targeted pharmacology. Current Pharmaceutical Design 9 1023-1031.

Combs TP, Wagner JA, Berger J, Doebber T, Wang WJ, Zhang BB, Tanen M, Berg AH, O'Rahilly S, Savage DB et al. 2002 Induction of adipocyte complement-related protein of 30 kilodaltons by PPARgamma agonists: a potential mechanism of insulin sensitization. Endocrinology 143 998-1007.

Combs TP, Pajvani UB, Berg AH, Lin Y, Jelicks LA, Laplante M, Nawrocki AR, Rajala MW, Parlow AF, Cheeseboro L et al. 2004 A transgenic mouse with a deletion in the collagenous domain of adiponectin displays elevated circulating adiponectin and improved insulin sensitivity. Endocrinology 145 367-383.

Davis KE, Moldes M \& Farmer SR 2004 The forkhead transcription factor FoxC2 inhibits white adipocyte differentiation. Journal of Biological Chemistry 279 4245-42461.

Fasshauer M, Klein J, Neumann S, Eszlinger M \& Paschke R 2001 Adiponectin gene expression is inhibited by beta-adrenergic stimulation via protein kinase A in 3T3-L1 adipocytes. FEBS Letters 507 142-146.

Fasshauer M, Klein J, Neumann S, Eszlinger M \& Paschke R 2002 Hormonal regulation of adiponectin gene expression in 3T3-L1 adipocytes. Biochemical and Biophysical Research Communications $2901084-1089$.

Fasshauer M, Kralisch S, Klier M, Lossner U, Bluher M, Klein J \& Paschke R 2003 Adiponectin gene expression and secretion is inhibited by interleukin6 in 3T3-L1 adipocytes. Biochemical and Biophysical Research Communications 301 1045-1050.

Festa A, D’Agostino R, Jr, Tracy RP \& Haffner SM 2002 Elevated levels of acute-phase proteins and plasminogen activator inhibitor- 1 predict the development of type 2 diabetes: the insulin resistance atherosclerosis study. Diabetes 51 1131-1137.

Freeman DJ, Norrie J, Caslake MJ, Gaw A, Ford I, Lowe GD, O'Reilly DS, Packard CJ \& Sattar N 2002 C-reactive protein is an independent predictor of risk for the development of diabetes in the west of scotland coronary prevention study. Diabetes 51 1596-1600.

Frohlich M, Imhof A, Berg G, Hutchinson WL, Pepys MB, Boeing H, Muche R, Brenner H \& Koenig W 2000 Association between C-reactive protein and features of the metabolic syndrome: a population-based study. Diabetes Care $\mathbf{2 3}$ 1835-1839.

Fruebis J, Tsao TS, Javorschi S, Ebbets-Reed D, Erickson MR, Yen FT, Bihain BE \& Lodish HF 2001 Proteolytic cleavage product of 30-kDa adipocyte complement-related protein increases fatty acid oxidation in muscle and causes weight loss in mice. PNAS 98 2005-2010.

Hotta K, Funahashi T, Arita Y, Takahashi M, Matsuda M, Okamoto Y, Iwahashi H, Kuriyama H, Ouchi N, Maeda K et al. 2000 Plasma 
concentrations of a novel, adipose-specific protein, adiponectin, in type 2 diabetic patients. Arteriosclerosis, Thrombosis, and Vascular Biology 20 1595-1599.

Hotta K, Funahashi T, Bodkin NL, Ortmeyer HK, Arita Y, Hansen BC \& Matsuzawa Y 2001 Circulating concentrations of the adipocyte protein adiponectin are decreased in parallel with reduced insulin sensitivity during the progression to type 2 diabetes in rhesus monkeys. Diabetes 50 1126-1133.

Kubota N, Terauchi Y, Yamauchi T, Kubota T, Moroi M, Matsui J, Eto K, Yamashita T, Kamon J, Satoh H et al. 2002 Disruption of adiponectin causes insulin resistance and neointimal formation. Journal of Biological Chemistry 277 25863-25866.

Li RY, Song HD, Shi WJ, Hu SM, Yang YS, Tang JF, Chen MD \& Chen JL 2004 Galanin inhibits leptin expression and secretion in rat adipose tissue and 3T3-L1 adipocytes. Journal of Molecular Endocrinology 33 11-19.

Libby P, Ridker PM \& Maseri A 2002 Inflammation and atherosclerosis. Circulation 105 1135-1143.

Lindsay RS, Funahashi T, Hanson RL, Matsuzawa Y, Tanaka S, Tataranni PA, Knowler WC \& Krakoff J 2002 Adiponectin and development of type 2 diabetes in the Pima Indian population. Lancet 360 57-58.

Lyon CJ, Law RE, Hsueh WA, Chaldakov GN, Stankulov IS, Hristova M \& Ghenev PI 2003 Minireview: adiposity inflammation, and atherogenesis. Endocrinology 144 2195-2200.

Maeda N, Takahashi M, Funahashi T, Kihara S, Nishizawa H, Kishida K, Nagaretani H, Matsuda M, Komuro R, Ouchi N et al. 2001 PPARgamma ligands increase expression and plasma concentrations of adiponectin, an adipose-derived protein. Diabetes 50 2094-2099.

Maeda N, Shimomura I, Kishida K, Nishizawa H, Matsuda M, Nagaretani H, Furuyama N, Kondo H, Takahashi M, Arita Y et al. 2002 Diet-induced insulin resistance in mice lacking adiponectin/ACRP30. Nature Medicine 8 731-737.

Marnell L, Mold C \& Du Clos TW 2005 C-reactive protein: ligands, receptors and role in inflammation. Clinical Immunology 7 104-111.

Ouchi N, Kihara S, Arita Y, Maeda K, Kuriyama H, Okamoto Y, Hotta K, Nishida M, Nakamura T et al. 1999 Novel modulator for endothelial adhesion molecules: adipocyte-derived plasma protein adiponectin. Circulation 100 2473-2476.

Ouchi N, Kihara S, Funahashi T, Nakamura T, Nishida M, Kumada M, Okamoto Y, Ohashi K, Nagaretani H, Kishida K et al. 2003 Reciprocal association of $\mathrm{C}$-reactive protein with adiponectin in blood stream and adipose tissue. Circulation 107 671-674.

Ridker PM, Hennekens CH, Buring JE \& Rifai N 2000 C-reactive protein and other markers of inflammation in the prediction of cardiovascular disease in women. New England Journal of Medicine 342 836-843.
Schulze MB, Rimm EB, Shai I, Rifai N \& Hu FB 2004 Relationship between adiponectin and glycemic control, blood lipids, and inflammatory markers in men with type 2 diabetes. Diabetes Care $\mathbf{2 7}$ 1680-1687.

Weyer C, Funahashi T, Tanaka S, Hotta K, Matsuzawa Y, Pratley RE \& Tataranni PA 2001 Hypoadiponectinemia in obesity and type 2 diabetes: close association with insulin resistance and hyperinsulinemia. Journal of Clinical Endocrinology Metabolism 86 1930-1935.

Xu A, Wong LC, Wang Y, Xu JY, Cooper GJ \& Lam KS 2004 Chronic treatment with growth hormone stimulates adiponectin gene expression in 3T3-L1 adipocytes. FEBS Letters 572 129-134.

Yamauchi T, Kamon J, Waki H, Terauchi Y, Kubota N, Hara K, Mori Y, Ide T, Murakami K, Tsuboyama-Kasaoka N et al. 2001 The fat-derived hormone adiponectin reverses insulin resistance associated with both lipoatrophy and obesity. Nature Medicine 7 941-946.

Yamauchi T, Kamon J, Minokoshi Y, Ito Y, Waki H, Uchida S, Yamashita S, Noda M, Kita S, Ueki K et al. 2002 Adiponectin stimulates glucose utilization and fatty-acid oxidation by activating AMP-activated protein kinase. Nature Medicine 8 1288-1295.

Yamauchi T, Kamon J, Waki H, Imai Y, Shimozawa N, Hioki K, Uchida S, Ito Y, Matsui J, Eto K et al. 2003 Globular adiponectin protected ob/ob mice from diabetes and ApoE-deficient mice from atherosclerosis. Journal of Biological Chemistry 24 2461-2468.

Yokota T, Oritani K, Takahashi I, Ishikawa J, Matsuyama A, Ouchi N, Kihara S, Funahashi T, Tenner AJ, Tomiyama Yet al. 2000 Adiponectin, a new member of the family of soluble defense collagens, negatively regulates the growth of myelomonocytic progenitors and the functions of macrophages. Blood 96 1723-1732.

Yuan G, Zhou L, Tang J, Yang Y, Gu W, Li F, Hong J, Gu Y, Li X, Ning G et al. 2006 Serum CRP levels are equally elevated in newly diagnosed type 2 diabetes and impaired glucose tolerance and related to adiponectin levels and insulin sensitivity. Diabetes Research and Clinical Practice $\mathbf{7 2}$ 244-250.

\author{
Received in final form 15 May 2007 \\ Accepted 23 May 2007 \\ Made available online as an Accepted Preprint
} 29 May 2007 